\title{
Climate Change and Tourism in the Asia Pacific
}

Edited by

Bruce Prideaux, Bob McKercher and Karen Elizabeth McNamara 


\section{Climate Change and Tourism in the Asia Pacific}

Climate change will exert an enormous impact on all societies in the medium to long term. Tourism, as both a commercial activity and social phenomenon is not immune. To date, industry has been slow to recognise the scale of the threat posed by a changing climate on its operations and consumers have been extremely reluctant to modify their travel behaviours. The Asia Pacific region is well on the way to being the $21^{\text {st }}$ Century powerhouse of tourism, however the manner in which it develops will, in part, be determined by how the global community responds to climate change. This book examines climate change issues related to tourism in the Asia Pacific region. Chapters discuss demand and supply side issues, explore government policy responses and introduce several new adaptation models. The book also calls for a more effective linking of social science research with the scientific discourse to create long term resolution of and adaptation to this issue.

This book was published as a special issue of Asia Pacific Journal of Tourism Research.

Bruce Prideaux is Professor of Marketing and Tourism Management at the Cairns campus of James Cook University. His interests include climate change issues, tourism transport issues, crisis management, marine tourism and rainforest tourism.

Bob McKercher is Professor of Tourism in the School of Hotel and Tourism Management at the Hong Kong Polytechnic University. He has broad ranging research interests including sustainability in its broader sense, tourism development, spatial analysis of tourism and special interest tourism.

Karen Elizabeth McNamara is a Lecturer in the School of Geography, Planning and Environmental Management at the University of Queensland. Karen has largely worked in the Asia Pacific region on areas relating to community-based climate change adaptation, human mobility, sustainable livelihoods and resilience. 
First published 2014

by Routledge

2 Park Square, Milton Park, Abingdon, Oxon, OX14 4RN, UK

and by Routledge

711 Third Avenue, New York, NY 10017, USA

Routledge is an imprint of the Taylor \& Francis Group, an informa business

(C) 2014 Asia Pacific Tourism Association

All rights reserved. No part of this book may be reprinted or reproduced or utilised in any form or by any electronic, mechanical, or other means, now known or hereafter invented, including photocopying and recording, or in any information storage or retrieval system, without permission in writing from the publishers.

Trademark notice: Product or corporate names may be trademarks or registered trademarks, and are used only for identification and explanation without intent to infringe.

British Library Cataloguing in Publication Data

A catalogue record for this book is available from the British Library

ISBN13: 978-0-415-74050-0

Typeset in Times New Roman

by Taylor \& Francis Books

\section{Publisher's Note}

The publisher accepts responsibility for any inconsistencies that may have arisen during the conversion of this book from journal articles to book chapters, namely the possible inclusion of journal terminology.

\section{Disclaimer}

Every effort has been made to contact copyright holders for their permission to reprint material in this book. The publishers would be grateful to hear from any copyright holder who is not here acknowledged and will undertake to rectify any errors or omissions in future editions of this book.

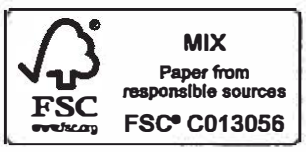




\section{Contents}

Citation Information vii

1. Introduction

Bruce Prideaux, Bob McKercher and Karen Elizabeth McNamara 1

2. Climate Change and Tourism: An Overview

Sharon F.H. Pang, Bob McKercher and Bruce Prideaux

3. The Critical Relationship between Climate Change Awareness

and Action: An Origin-Based Perspective

Tina Roenhovde Tiller and Christian Schott

4. Responding to Climate Change: Australian Tourism Industry

Perspectives on Current Challenges and Future Directions

Lisa Ruhanen and Aishath Shakeela

5. Policy Environment for the Tourism Sector's Adaptation to

Climate Change in the South Pacific - The Case of Samoa

Emma Wong, Min Jiang, Louise Klint, Terry DeLacy,

David Harrison and Dale Dominey-Howes

6. Operators' Perceptions of Energy Use and Actual Saving

Opportunities for Tourism Accommodation

Susanne Becken

7. Hospitality Industry Responses to Climate Change:

A Benchmark Study of Taiwanese Tourist Hotels

Yi-Ping Su, C. Michael Hall and Lucie Ozanne

8. Attitudes of Tourism Students to the Environment and Climate Change

Bob McKercher, Bruce Prideaux and Sharon F.H. Pang

9. Using a Regional Tourism Adaptation Framework to

Determine Climate Change Adaptation Options for Victoria's

Surf Coast

Ryan Jopp, Terry DeLacy, Judith Mair and Martin Fluker

10. Modelling a Tourism Response to Climate Change Using a

Four Stage Problem Definition and Response Framework

Bruce Prideaux, Bob McKercher and Karen Elizabeth McNamara

Index 



\section{Citation Information}

The chapters in this book were originally published in the Asia Pacific Journal of Tourism Research, volume 18, issue 1-2 (January-March 2013). When citing this material, please use the original page numbering for each article, as follows:

\section{Chapter 1}

\section{Editorial}

Bruce Prideaux, Bob McKercher and Karen Elizabeth McNamara

Asia Pacific Journal of Tourism Research, volume 18, issue 1-2 (January-March 2013) pp. 1-3

\section{Chapter 2}

Climate Change and Tourism: An Overview

Sharon F.H. Pang, Bob McKercher and Bruce Prideaux

Asia Pacific Journal of Tourism Research, volume 18, issue 1-2 (January-March 2013) pp. 4-20

\section{Chapter 3}

The Critical Relationship between Climate Change Awareness and Action: An OriginBased Perspective

Tina Roenhovde Tiller and Christian Schott

Asia Pacific Journal of Tourism Research, volume 18, issue 1-2 (January-March 2013) pp. 21-34

\section{Chapter 4}

Responding to Climate Change: Australian Tourism Industry Perspectives on Current Challenges and Future Directions

Lisa Ruhanen and Aishath Shakeela

Asia Pacific Journal of Tourism Research, volume 18, issue 1-2 (January-March 2013) pp. 35-51

\section{Chapter 5}

Policy Environment for the Tourism Sector's Adaptation to Climate Change in the South Pacific - The Case of Samoa

Emma Wong, Min Jiang, Louise Klint, Terry DeLacy, David Harrison and Dale Dominey-Howes 


\section{CITATION INFORMATION}

Asia Pacific Journal of Tourism Research, volume 18, issue 1-2 (January-March 2013) pp. 52-71

\section{Chapter 6}

Operators' Perceptions of Energy Use and Actual Saving Opportunities for Tourism Accommodation

Susanne Becken

Asia Pacific Journal of Tourism Research, volume 18, issue 1-2 (January-March 2013) pp. $72-91$

\section{Chapter 7}

Hospitality Industry Responses to Climate Change: A Benchmark Study of Taiwanese Tourist Hotels

Yi-Ping Su, C. Michael Hall and Lucie Ozanne

Asia Pacific Journal of Tourism Research, volume 18, issue 1-2 (January-March 2013) pp. $92-107$

\section{Chapter 8}

Attitudes of Tourism Students to the Environment and Climate Change

Bob McKercher, Bruce Prideaux and Sharon F.H. Pang

Asia Pacific Journal of Tourism Research, volume 18, issue 1-2 (January-March 2013) pp. 108-143

\section{Chapter 9}

Using a Regional Tourism Adaptation Framework to Determine Climate Change Adaptation Options for Victoria's Surf Coast

Ryan Jopp, Terry DeLacy, Judith Mair and Martin Fluker

Asia Pacific Journal of Tourism Research, volume 18, issue 1-2 (January-March 2013) pp. 144-164

\section{Chapter 10}

Modelling a Tourism Response to Climate Change Using a Four Stage Problem Definition and Response Framework

Bruce Prideaux, Bob McKercher and Karen Elizabeth McNamara

Asia Pacific Journal of Tourism Research, volume 18, issue 1-2 (January-March 2013) pp. 165-182

Please direct any queries you may have about the citations to clsuk.permissions@cengage.com 


\section{Introduction}

Climate change is an issue that is not yet taken seriously enough by many tourism academics or the industry. The Intergovernmental Panel on Climate Change concludes that the world's climate is changing and that the cause is most likely due to human activities over the past 200 years. While impacts for the most part are yet to be felt, early signs are already evident in some areas. Tourism is both a contributor to and a potential victim of climate change. Given the importance of this issue in the Asia Pacific region it is timely for tourism researchers to commence a more rigorous program of research directed at assessing the potential effects on the tourism industry and developing strategies for dealing with its effects.

The aim of this special issue is to promulgate research that relates specifically to aspects of climate change and tourism within the Asia Pacific region. To this end the papers in this special issue address a range of issues that collectively: illustrate the extent of the problem; discuss how it can be understood from consumer, supply and demand perspectives; the importance of the policy environment; and the need for more effective linking of elements of the scientific discourse with both theoretical and private/public sector responses. In particular, papers discuss how many industry stakeholders are uncertain as to how to respond in the absence of specific climate- related government policy frameworks. There is also a recognition of the need to create data bases that can be used to build long-term monitoring of impacts along with the need for more effective integration of climate change science and social science research.

The special issue is framed by two papers. To begin, an overview paper by Pang, McKercher and Prideaux sets the context and reviews some of the key literature on climate change and tourism. The paper traces the growth in academic interest in issues related to climate change. Tourism has consistently represented about $0.5 \%$ of the published research on climate change. The paper concludes with the observation that tourism researchers are now beginning to pay serious attention to climate change and the implications it has for the future shape and scope of the tourism industry. The paper also observes that there remains a number of gaps in our understanding of the future implications that climate change has for the tourism industry.

The concluding paper by Prideaux, McKercher and McNamara outlines a new theoretical approach to aid the examination of issues relating to climate change by presenting a framework of four linked models that allows users to identify firstly the issues to be examined and then examine specific aspects in detail. The paper identifies the need for tourism researchers to embrace the scientific 
literature relevant to their area of interest. For example, in research into the impact of climate change on coral reef systems the authors emphasise the need to consult the relevant scientific literature to gain at least a basic understand how climate change affects the reef ecosystem in areas such as coral bleaching. The authors also note the difficulty that the tourism industry faces in planning future responses to climate change in the absence of government policy that may be some time away.

In between, seven papers are presented that explore various themes.

Tiller and Schott explore the relationship between awareness of climate change and the willingness of tourists to support mitigation strategies that directly affect the cost of holiday travel. While tourists are aware that tourism contributes to climate change most are unlikely to change their pattern of holiday travel, pointing to a "attitude-behaviour gap". One concerning finding is the identification of a group of tourists likely to increase their travel "to see things before they are gone".

Ruhanen and Shakeela highlight the need to consider climate change as a national issue and one that both the private and public sectors need to come to grips with. The paper examines how climate change may impact on Australia at a nationwide level. The authors find that it is not seen as a pressing issue, particularly when compared to the more short term but significant issues stemming from the 2008/2009 global economic crisis, and its continuing aftermath. As a consequence, there has been little action by industry in responding to climate change. Importantly, and paralleling findings of other papers in this special issue, the tourism industry is relying on, and waiting for, government intervention and leadership on strategies to respond to climate change. As the authors note, the long-term nature of change is the major reason for a lack of action in the short term while uncertainty of future government intentions is inhibiting the development of proactive initiatives.

Wong, Jiang, Klint, DeLacy, Harrison and Dominey-Howes provide a useful case study of how one country, in this case Samoa, is seeking to proactively respond to climate change through extensive policy intervention. Specifically, the paper examines the conduciveness of the Samoan policy environment for the tourism sector to adapt to climate change along three dimensions: stakeholders' will and commitment, resources available and policymaking mechanisms. Samoa provides an exemplar case study for understand how islands can best adapt to climate change. Finally, the paper notes that while the policy environment is generally conducive there is a need for closer public-private cooperation.

Becken turns the reader's attention to one of the specific links between tourism and climate change by examining current practices and opportunities for achieving energy efficiency in the New Zealand accommodation sector. Of particular importance is the finding that a substantial gap was identified between the positive perceptions held by operators and the actual levels of implementation. As Becken points out, while there is extensive theoretical knowledge on overcoming some of the barriers to energy efficiency and conservation, a gap still remains between policy to achieve energy efficiencies and implementation of measures to achieve efficiency by individual business.

Su, Hall and Ozanne's paper on hotels complements Becken's paper by examining issues related to the response of the Taiwanese hospitality sector to climate change. Specially, the paper finds that hotels are particularly vul- 
nerable to climate change given that they are fixed assets. The paper first explores issues related to the awareness, attitudes, and behaviours of Taiwanese tourist hotels. The paper finds that in general hotels have a limited understanding of the potential impacts. Importantly, the paper provides baseline data that may be used in to identify changes in hotel attitudes in the future.

McKercher, Prideaux and Pang report on the results of a study into attitudes towards climate change of 2967 students from 22 economies. The results provide a unique snapshot of how the industry's future leaders view climate change. Students are generally concerned about environmental degradation, feel knowledgeable about climate change, are concerned that it will become an even larger problem in the future and understand that tourism is a major generator of carbon emissions. Significantly, $70 \%$ of respondents reported changing their environmental behaviours in the past three years. However, only less than $13 \%$ of students have changed their vacation behaviour. The authors also high- lighted the potential for the study to provide a baseline for understanding of student attitudes in future years.

Jopp, DeLacy, Mair and Flucker outline a regional tourism adaptation framework model that can be used by destination areas as they develop their responses to climate change. The data for the model were collated through a Delphi study using a panel of experts who had appropriate knowledge of the Surf Coast, Victoria, Australia. The framework model was designed to be used as a tool to undertake a vulnerability resilience assessment from which strategies for destinations resilience, resistance and readiness may be developed.

We hope you enjoy this Special issue. More significantly, we hope it stimulates further debate and research on tourism's relationship with climate change.

Bruce Prideaux

Bob McKercher

Karen Elizabeth McNamara 